\section{A technique for rapid isolation of macrophages from guinea-pig peritoneal exudates}

M. KNOWLES AND D. HUGHeS From the Medical Research Council Demyelinating Diseases Unit, Newcastle General Hospital, Westgate Road, Newcastle upon Tyne

Preparations of pure macrophage suspensions may be required in the investigation of cellmediated immune reactions or for the preparation of antimacrophagic serum. Methods for the preparation of macrophage suspensions of high purity from peritoneal exudates are relatively tedious and result in small yields of cells. Bloom and Bennett (1966) and Turk and Polak (1967) describe a technique in,which guinea-pig peritoneal exudates are incubated in Petri dishes at $37^{\circ} \mathrm{C}$ in an atmosphere containing $10 \% \mathrm{CO}_{2}$ for four to 24 hours. Those cells which adhere to the glass surface and cannot be removed by vigorous shaking are released by treatment with a $1 / 5000$ solution of ethylenediamine tetraacetic acid. They reported their cell preparations to contain $99.4 \%$ to $99.8 \%$ macrophages but yields were not given. This technique depends on the property of macrophages to stick firmly to a glass surface, which distinguishes them from lymphocytes.

An albumin gradient sedimentation method described by Vallee, Hughes, and Gibson (1947) has been applied to the problem of isolating tumour cells from human peripheral blood (Roberts, Wayne, McGarth, McGrew, and Cole, 1958) and a modification was used for a similar purpose by Spriggs and Alexander (1960). We report here the use of a simple column of two layers of bovine serum albumin to effect differential sedimentation of guinea-pig peritoneal exudate cells.

\section{Method}

Exudates were induced in Hartley guinea pigs of $450 \mathrm{~g}$ to $800 \mathrm{~g}$ weight by intraperitoneal injection of $20 \mathrm{ml}$ sterile liquid paraffin. Exudates were harvested after six to 14 days by intraperitoneal injection of $50 \mathrm{ml}$ heparinized Hanks balanced salt solution ( 5 units heparin/ml). The exudate suspensions were withdrawn and centrifuged in conical tubes at $250 \mathrm{~g}$ for 10 minutes. The cell pellets were taken up in $1 \mathrm{ml}$ volumes of Hanks solution and transferred to a single 10 $\mathrm{ml}$ centrifuge tube and washed twice in Hanks solution. Cell yields ranged from $80 \times 10^{6}$ to $250 \times 10^{6}$ leucocytes. Maximum yields were obtained nine to 13 days after injection of liquid paraffin, and showed no close relation to the

Received for publication 25 March 1970. size of the animal. Cell populations contained $\stackrel{\rho}{=}$ $5 \%$ to $15 \%$ lymphocytes. Considerable difficulty was encountered in the identification of some cells. A lymphocyte was considered to be a smallo round cell with a deeply staining nucleus, a thin rim of pale blue cytoplasm when stained witho buffered Giemsa, and at most minute vacuoles.

For differential sedimentation two layers of bovine serum albumin (BSA, fraction V, Armour) $\overline{\overline{\bar{D}}}$ were used. A column was made in a siliconed ${ }_{\odot}$ $10 \mathrm{ml}$ centrifuge tube of $2 \mathrm{ml}$ ' $20 \%$ ' BSA in Hanks solution ( 2 g BSA +10 ml Hanks) onto which a similar volume of ' $5 \%$ ' BSA in? Hanks solution was carefully placed so that the interphase was not disturbed. Exudate cells, $\stackrel{\omega}{\sigma}$ taken up in 2 to $3 \mathrm{ml}$ of Hanks solution, were then carefully layered onto the BSA gradient andis centrifuged at $450 \mathrm{~g}$ for 10 minutes. The exudate ${ }_{0}^{\omega}$ cells separated out into three distinct layers. $\infty$ Paraffin globules floated on the surface of the Hanks solution, whilst cell debris remained on음 the surface of the ' $5 \%$ ' BSA layer. Lymphocytes, erythrocytes, and some of the macrophages? formed a pellet at the bottom of the tube, whilst between the two layers of BSA was a thick layer 3 of macrophages. This layer gave yields of $20 \%$ to $50 \%$ of the total available macrophages and consisted of $99 \%$ to $100 \%$ of these cells. The majority of these macrophages contained more. than one large paraffin-filled vacuole, so it? seems probable that the mechanism of separation $\sum$ depends on a decrease in density caused by inges-ō tion of paraffin.

This method is less satisfactory for the isolation $\stackrel{\odot}{\otimes}$ of pure lymphocyte suspensions from the same $\vec{\overrightarrow{ }}$ exudate since, although lymphocyte-enriched 3 populations may be obtained, macrophagic $\rightleftharpoons$ contamination is always present. Lymphocytes? may be rapidly obtained from the same animal as peritoneal exudates using heparinized or defi-: brinated blood with the carbonyl iron ingestion- $-\frac{3}{3}$ methyl cellulose sedimentation method of Coulson: and Chalmers (1966) as modified by Hughes and $\frac{\odot}{3}$ Caspary (1970).

Using the technique of Bloom and Bennett ? (1966) we experienced a recovery of 10 to $20 \%$ of total available macrophages, sometimes contaminated with $5 \%$ lymphocytes. The BSA column offers the advantage of being a rapid (less than one hour) and consistent method of obtaining large numbers of macrophages.

We should like to thank Mr A. Keith, FIAT, who was responsible for management of the animals and removal of peritoneal exudates.

\section{References}

Bloom, B. R., and Bennett, B. (1966). Mechanism of a reaction in vitro associated with delayed-type hypersensitivity. Science, 153, 80-82. 
Coulson, A. S., and Chalmers, D. G. (1967). Response of human blood lymphocytes to tuberculin PPD in tissue culture. Immunology, 12, 417-429.

Hughes, D., and Caspary, E. A. (1970). Lymphocyte transformation in vitro measured by tritiated thymidine uptake. I. Lymphocyte culture techniques. Int. Arch. Allergy, $37,506-531$.

Roberts, S., Watne, A., McGrath, R., McGrew, E., and Cole, W. H. (1958). Technique and results of isolation of cancer cells from the circulating blood. AMA Arch. Surg., 76, 334-346.
Spriggs, A. I., and Alexander, R. F. (1960). An albumin gradien method for separating the different white cells of blood applied to the concentration of circulating tumour cells. Nature (Lond.), 188, 863-864.

Turk, J. L., and Polák, L. (1967). Studies on the origin and reactive ability in vivo of peritoneal exudate cells in delayed. hypersensitivity. Int. Arch. Allergy, 31, 403-416.

Vallee, B. L., Hughes, W. L. Jr., and Gibson, J. G., II. (1947) $\stackrel{\overrightarrow{\mathcal{S}}}{\rightarrow}$ A method for separation of leukocytes from whole blood by flotation on serum albumin. Blood (Special Issue) No. 1, 82-87.

\section{Letter to the Editor}

\section{The Disposable Glass Culture Tube as a Cuvette}

Since October 1967 we have had extensive experience using disposable test tubes as disposable cuvettes in haema- passing a broad beam of light through the cuvette lead to erratic results. Larger tubes, $16 \mathrm{~mm}$ and $19 \mathrm{~mm}$ diameters, are not uniform. The thin-walled disposable flint glass and borosilicate tubes made by Kimble have been mainly used. We have also had experience with Pyrex tubes by Corning.

The uniformity of the disposable test tubes seems equal to commercially available cuvettes and superior to re-used cuvettes that are scratched and routinely used as demonstrated in the Table below.

The disposable cuvette is faster and more trouble-free than flow-through cuvettes and has increased the output in our clinical chemistry section. The disposable test tube costs approximately 1.3 cents (US) each. Besides the convenience of being disposable, they are packaged clean and free of scratches. new supplier. The thick-walled tubes ? are not optically uniform for use as disposable cuvettes.

We have not noticed any significant increase in day-to-day precision on 3 aliquots of frozen pooled serum for the tests used in clinical chemistry. For haemoglobinometry, using a cyanmeth- $\theta$ aemoglobin method over a two-yearo period and aliquots of frozen citratedo whole blood, our day-to-day precision, \& as $2 \mathrm{SD}$, varied from 0.4 to $0.5 \mathrm{mg}$ per $100 \mathrm{ml}$ using specimens with mean values of 12 to $13 \mathrm{~g}$ per $100 \mathrm{ml}$.

We conclude that the use of 10 to $13 \mathrm{~mm} \stackrel{\mathrm{D}}{2}$ diameter thin-walled disposable glass $\vec{F}$ tubes as disposable cuvettes is justified. Verification of our experience should be sought if one wishes to use disposable test tubes or instruments other than those found satisfactory in this communication.

\begin{tabular}{|c|c|c|c|c|c|}
\hline \multirow[t]{2}{*}{ Type of Tube } & \multirow[t]{2}{*}{ No. of Tubes } & \multicolumn{3}{|l|}{$O D$} & \multirow{2}{*}{$\begin{array}{l}2 C V \\
(\%)\end{array}$} \\
\hline & & Mean & Range & $2 S D$ & \\
\hline $\begin{array}{l}\text { Spectronic } 20 \text { cuvette, from daily } \\
\text { reused supply } \\
\text { Spectronic } 20 \text { cuvette, selected for }\end{array}$ & 42 & 0.468 & $0.455-0.490$ & 0.020 & $4 \cdot 2$ \\
\hline $\begin{array}{l}\text { adequate condition }{ }^{2} \\
\text { Disposable, flint glass culture tube }\end{array}$ & $\begin{array}{r}32 \\
275\end{array}$ & $\begin{array}{l}0.464 \\
0.455\end{array}$ & $\begin{array}{l}0.455-0.480 \\
0.442-0.465\end{array}$ & $\begin{array}{l}0.014 \\
0.010\end{array}$ & $\begin{array}{l}3 \cdot 0 \\
2 \cdot 2\end{array}$ \\
\hline
\end{tabular}

\section{Table Optical densities of cuvettes and disposable tubes with rotation}

${ }^{1}$ On inspection, some of these were noticeably scratched.

${ }^{2}$ These were inspected, so that they were all unscratched.

tology for doing haemoglobin determinations and in clinical chemistry generally. The 13 by $100 \mathrm{~mm}$ test tubes are most convenient, but we have had experience with 12 by $75 \mathrm{~mm}$ and 10 by $75 \mathrm{~mm}$ tubes as well. We have extensively used the Coleman Jr, Coleman Jr II, and the Spectronic 20 spectrophotometers; some personal experience with instruments
We have recently changed over to the routine use of borosilicate as we noted the presence of residual alkali in the flint glass tubes. However, we did not encounter any interference due to residual alkali which was probably buffered by patients' specimens and/or reagents. Recently we have seen a thickwalled grade of disposable tubes from a
IRWIN SCHOEN $\stackrel{?}{-}$ Division of Pathology, Cedars-Sinai Medical Center, $\underset{\oplus}{\stackrel{+}{+}}$ P.O. Box 54723, Los Angeles, California $90048 \stackrel{\odot}{\circ}$ EDWARD L. ELLSWORTH USPHS National Center for Air Pollution Control, Cincinnati, Ohio 45237흘 